\title{
Validation of a novel fluorescent lateral flow assay for rapid qualitative and quantitative assessment of total anti-SARS-CoV-2 S-RBD binding antibody units (BAU) from plasma or fingerstick whole-blood of COVID-19 vaccinees
}

Nadin Younes ${ }^{1,2, \dagger}$, Duaa W. Al-Sadeq ${ }^{1,3, \dagger}$, Farah M. Shurrab ${ }^{1,2},{ }^{1}$, Hadeel T. Zidan ${ }^{1,2}$, Haissam Abou-Saleh $^{4}$, Bushra Y. Abo Halawa ${ }^{4}$, Fatima M. AlHamaydeh ${ }^{2}$, Amira E. Elsharafi ${ }^{2}$, Hanin I. Daas ${ }^{5}$, Swapna Thomas ${ }^{1,2}$, Sahar Aboalmaaly ${ }^{6}$, Afra Al Farsi ${ }^{6}$, Reeham Al-Buainain ${ }^{6}$, Samar Ataelmannan ${ }^{6}$, Jiji Paul ${ }^{6}$, Amana Salih Al Saadi ${ }^{6}$, Hadi M. Yassine ${ }^{1,2}$, Amin F. Majdalawieh $^{7}$, Ahmed Ismail ${ }^{6}$, Laith J. Abu-Raddad ${ }^{8,9,10}$, Gheyath K. Nasrallah ${ }^{1,2, *}$

${ }^{1}$ Biomedical Research Center, Qatar University, 2713 Doha, Qatar.

${ }^{2}$ Department of Biomedical Science, College of Health Sciences, Member of QU Health, Qatar University, 2713 Doha, Qatar.

${ }^{3}$ College of Medicine, Member of QU Health, Qatar University, 2713 Doha, Qatar.

${ }^{4}$ Department of Biological and Environmental Sciences, College of Arts and Sciences, Qatar University, 2713 Doha, Qatar.

${ }^{5}$ College of Dental Medicine, QU Health, Qatar University, 2713 Doha, Qatar.

${ }^{6}$ Laboratory Section, Medical Commission Department, Ministry of Public Health, 42 Doha, Qatar

${ }^{7}$ Department of Biology, Chemistry and Environmental Sciences, College of Arts and Sciences, American University of Sharjah, 26666 Sharjah, United Arab Emirates.

${ }^{8}$ Infectious Disease Epidemiology Group, Weill Cornell Medicine-Qatar, Cornell University, Qatar Foundation-Education City, 24144 Doha, Qatar

${ }^{9}$ World Health Organization Collaborating Centre for Disease Epidemiology Analytics on HIV/AIDS, Sexually Transmitted Infections, and Viral Hepatitis, Weill Cornell Medicine-Qatar, Cornell University, Qatar Foundation-Education City, 24144 Doha, Qatar

${ }^{10}$ Department of Healthcare Policy and Research, Weill Cornell Medicine, Cornell University, New York, NY 10065, USA

* Correspond to: Gheyath K. Nasrallah

Department of Biomedical Science, College of Health Sciences, Qatar University, Doha, Qatar Women's Science building, C01, Tel: +974 4403 4817, Fax: +974-4403-1351, P.O. Box: 2713, email: gheyath.nasrallah@qu.edu.qa. 
medRxiv preprint doi: https://doi.org/10.1101/2022.01.04.22268754; this version posted January 5, 2022. The copyright holder for this preprint (which was not certified by peer review) is the author/funder, who has granted medRxiv a license to display the preprint in perpetuity.

All rights reserved. No reuse allowed without permission.

\section{Abstract}

2 Background: Limited commercial LFA assays are available to provide a reliable quantitative

3 measurement of the total binding antibody units (BAU/mL) against the receptor-binding

4 domain of the SARS-CoV-2 spike protein (S-RBD). Aim: To evaluate the performance of

5 FinecareTM2019-nCoV S-RBD LFA and its fluorescent reader (FinecareTM-FIA Meter)

6 against the following reference methods (i) The FDA-approved Genscript surrogate virus-

7 neutralizing assay (sVNT), and (ii) three highly performing automated immunoassays:

8 BioMérieux VIDAS®3, Ortho VITROS®, and Mindray CL-900i®. Methods: Plasma from

9488 vaccinees were tested by all aforementioned assays. Fingerstick whole-blood samples

10 from 156 vaccinees were also tested by FinecareTM. Results and conclusions: FinecareTM

11 showed $100 \%$ specificity as none of the pre-pandemic samples tested positive. Equivalent

12 FinecareTM results were observed among the samples taken from fingerstick or plasma

13 (Pearson correlation $r=0.9, \mathrm{p}<0.0001$ ), suggesting that fingerstick samples are sufficient to

14 quantitate the S-RBD BAU/mL. A moderate correlation was observed between FinecareTM

15 and $\operatorname{sVNT}(r=0.5, \mathrm{p}<0.0001)$, indicating that FinecareTM can be used for rapid prediction of

16 the neutralization antibody post-vaccination. FinecareTM BAU results showed strong

17 correlation with VIDAS $₫ 3(r=0.6, \mathrm{p}<0.0001)$, and moderate correlation with VITROS $®$

$18(r=0.5, \mathrm{p}<0.0001)$, and CL-900i ${ }^{\circledR}(r=0.4, \mathrm{p}<0.0001)$, suggesting that FinecareTM be used as

19 a surrogate for the advanced automated assays to measure S-RBD BAU/mL.

20

21 Keywords: SARS-CoV-2; COVID-19; Serology; Lateral Flow Assay; Automated

22 immunoassay; CLIA; Neutralizing antibodies; Surrogate virus neutralization test (sVNT). 
medRxiv preprint doi: https://doi.org/10.1101/2022.01.04.22268754; this version posted January 5, 2022. The copyright holder for this preprint (which was not certified by peer review) is the author/funder, who has granted medRxiv a license to display the preprint in perpetuity.

All rights reserved. No reuse allowed without permission.

23

\section{Introduction}

Serological immunoassays are rapidly emerging with varying degrees of sensitivity and specificity $(1,2)$. These include enzyme-linked immunosorbent assays (ELISAs), chemiluminescence assays (CLIA), electrofluorescent (ELFA), and lateral flow assays (LFAs). Most serological assays measure the binding antibodies (BA) response against specific SARS-CoV-2 antigens. Measuring binding antibodies is insufficient for assessing protective immunity since these antibodies (Abs) do not play significant roles in virus neutralization $(3,4)$. neutralizing antibodies (nAbs) are more indicative of protective immunity due to their ability not only to bind S-RBD, but also to block viral entry to the host cells $(3,5-8)$. Therefore, neutralization assays remain the gold standard for measuring the nAbs titer against SARS-CoV-2 (9). Nevertheless, nAb assays require high-level biosafety laboratories, highly trained personnel and often take several days to complete (9). To avoid such limitations, Genscript Biotech Corporation developed a reliable surrogate virusneutralizing assay (known as sVNT or cPass) to measure the nAb. The cPass Genscript assay is now recommended by the World Health Organization (WHO) and also received the full USA FDA approval to be used as a reference assay for quantitative measurement of the nAb (10).

One of the major challenges for the commercially available serology assays is that their binding antibody results are provided in arbitrary units per milliliters (ARU/mL). Thus, the results between assays are highly variable, although they target the same SARS-CoV-2 antigen, usually the S-protein. To minimize the discrepancies between serological assays, the WHO introduced an international standard to harmonize the antibodies immune response assessment and recommended reporting the assay results for binding activity in binding antibody unit per milliliter (BAU/mL) instead of arbitrary ARU/mL. (11). One of the best ways to identify a reliable assay that can be used as a surrogate assay to assess the quantity of 
medRxiv preprint doi: https://doi.org/10.1101/2022.01.04.22268754; this version posted January 5, 2022. The copyright holder for this preprint (which was not certified by peer review) is the author/funder, who has granted medRxiv a license to display the preprint in perpetuity.

All rights reserved. No reuse allowed without permission.

neutralizing Abs post-vaccination is by performing correlation studies between these assays and a reference neutralization assay.

LFAs are attractive for small or non-laboratory settings and population surveillance.

They are affordable and rely on easily accessible specimens such as fingerstick whole blood, and provide the result within minutes. According to the literature, none of the few commercially available fluorescent LFAs that provide quantitative measurement of SARSCoV-2 (in BAU/mL) to the S-RBD protein was validated. The FinecareTM2019-nCoV SRBD Antibody Test is a fluorescence immunoassay used along FinecareTM FIA Meters (reader) (Model No.: FS-113) for quantitative detection of S-RBD BAU in human fingerstick whole blood, venipuncture whole blood, and serum or plasma specimens (12). For more information about the assay principle, see Figure S1. In this study, we aimed to evaluate the performance of FinecareTM2019-nCoV by comparing its results with (i) the Genescript a surrogate virus-neutralizing test (sVNT), and (ii) three highly performing commercially available automated anti-SARS-CoV-2 immunoassays; Mindray CL-900i® SARS-CoV-2 SRBD IgG and BioMérieux VIDAS®3, which measure BAU for S-RBD $(13,14)$, and Ortho VITROS®, which measures total BAU to the $\mathrm{S} 1$ spike protein subunit $(13,14)$.

\section{Methods}

\subsection{Samples collection and ethical approval}

Participants who received two BNT162b2 or mRNA-1273 vaccine doses were eligible for inclusion. A total of 488 EDTA whole-blood samples $(5.0 \mathrm{~mL})$ were collected between April and October 2021 from staff and students at Qatar University, the largest national university in Qatar. Plasma was separated from whole venous blood and stored at $80^{\circ} \mathrm{C}$ until performing the test. Demographic information and information on the previous infection with SARS-CoV-2 were collected through a self-administered questionnaire. Out of the total samples, 156 participants in the vaccinated group performed the FinecareTM test 
medRxiv preprint doi: https://doi.org/10.1101/2022.01.04.22268754; this version posted January 5, 2022. The copyright holder for this preprint (which was not certified by peer review) is the author/funder, who has granted medRxiv a license to display the preprint in perpetuity.

All rights reserved. No reuse allowed without permission.

73 with fingerstick whole blood. The study was reviewed and approved by the Institutional

74 Review Board at Qatar University (QU-IRB 1537-FBA/21). All analyses were conducted

75 according to the ethical standards of the Declaration of Helsinkiof the World Medical

76 Association (WMA).

77

\subsection{FincareFinecareTM anti-SARS-CoV-2 S-RBD total antibodies test}

\subsubsection{Fingerstick samples}

Briefly, the area of the fingertip was lanced with an alcohol pad. Then, the skin was punctured using a sterile lancet, and $20 \mu \mathrm{L}$ of fingerstick blood was collected with the capillary sampler. The specimen was squeezed out into the detection buffer tube. After that, $75 \mu \mathrm{L}$ of sample mixture was loaded into the sample well and was inserted into the Test Cartridge holder of FinecareTM FIA Meters. The reaction time is 15 minutes. The results unit is displayed as a relative fluorescence unit (RFU, AU/mL). To obtain the results in $\mathrm{BAU} / \mathrm{mL}$, the $\mathrm{AU} / \mathrm{mL}$ values were multiplied by the WHO standard (20) that is provided by the manufacturer.

\subsubsection{Plasma samples}

According to the standard phlebotomy procedure, venipuncture whole blood specimens were collected from each participant in EDTA tubes. Then, plasma was separated from blood immediately, and the test was performed as described above in 2.2.1.

\subsection{Commercially available serological assays}

Samples were analyzed using three commercially available automated anti-SARSCoV-2 immunoassays assays: Mindray CL-900i® SARS-CoV-2 IgG (Cat. No. SARS-CoV-2 S-RBD IgG122, Mindray, Shenzhen, China), VIDAS®3 SARS-CoV-2 IgG (Cat. No. 423834, BioMérieux, Marcy-l'Étoile, France), and Ortho VITROS ${ }^{\circledR}$ anti-SARS-CoV-2 total Ab (Ortho Clinical Diagnostics, USA). Each assay was performed according to the manufacturer's instructions. The characteristics of the assays, including detection method, 
medRxiv preprint doi: https://doi.org/10.1101/2022.01.04.22268754; this version posted January 5, 2022. The copyright holder for this preprint

(which was not certified by peer review) is the author/funder, who has granted medRxiv a license to display the preprint in perpetuity.

All rights reserved. No reuse allowed without permission.

99 targeted antigens, sample volume, result interpretation, reported sensitivity and specificity,

100 and WHO conversion factor to BAU/mL are summarized in Table 1.

101 Table 1. Characteristics of the automated analyzers used in this study.

\begin{tabular}{|c|c|c|c|c|c|c|c|c|c|}
\hline $\begin{array}{c}\text { Manfac } \\
\text { turer }\end{array}$ & $\begin{array}{c}\text { Autom } \\
\text { ated } \\
\text { Analyz } \\
\text { er }\end{array}$ & $\begin{array}{c}\text { Detec } \\
\text { tion } \\
\text { Meth } \\
\text { od }\end{array}$ & $\begin{array}{c}\text { Targ } \\
\text { eted } \\
\text { Antig } \\
\text { en }\end{array}$ & $\begin{array}{c}\text { Samp } \\
\text { le } \\
\text { Volu } \\
\text { me }\end{array}$ & $\begin{array}{c}\text { Result } \\
\text { Interpre } \\
\text { tation }\end{array}$ & $\begin{array}{c}\text { Repor } \\
\text { ted } \\
\text { Sensit } \\
\text { ivity } \\
\end{array}$ & $\begin{array}{c}\text { Repor } \\
\text { ted } \\
\text { Specif } \\
\text { icity }\end{array}$ & $\begin{array}{l}\text { WHO } \\
\text { Conve } \\
\text { rsion } \\
\text { Factor }\end{array}$ & $\begin{array}{c}\text { Refer } \\
\text { ence }\end{array}$ \\
\hline $\begin{array}{l}\text { Mindray } \\
\text { Bio- } \\
\text { Medical } \\
\text { Electron } \\
\text { ics Co., } \\
\text { Ltd. }\end{array}$ & $\begin{array}{c}\text { Mindra } \\
\text { y CL- } \\
\text { 900i® } \\
\text { SARS- } \\
\text { CoV-2 } \\
\text { S-RBD } \\
\text { IgG }\end{array}$ & $\underset{*}{\text { CLIA }}$ & $\begin{array}{l}\text { S- } \\
\text { RBD }\end{array}$ & $\begin{array}{l}10 \mu \mathrm{L} \\
\text { (this } \\
\text { volum } \\
\text { e does } \\
\text { not } \\
\text { includ } \\
\text { e the } \\
\text { dead } \\
\text { volum } \\
\text { e) }\end{array}$ & $\begin{array}{c}<10 \\
\text { AU/mL: } \\
\text { Negative } \\
\geq 10 \\
\text { AU/mL: } \\
\text { Positive }\end{array}$ & $\begin{array}{l}100 \% \\
(\geq 15 \\
\text { days })\end{array}$ & $94.9 \%$ & 1.15 & $\begin{array}{l}(15, \\
16)\end{array}$ \\
\hline $\begin{array}{l}\text { BioMéri } \\
\text { eux } \\
\text { Diagnos } \\
\text { tics }\end{array}$ & $\begin{array}{c}\text { VIDA } \\
\text { S®3 } \\
\text { SARS- } \\
\text { CoV-2 } \\
\text { IgG }\end{array}$ & $\underset{*}{\text { ELFA }}$ & $\begin{array}{c}\text { S- } \\
\text { RBD }\end{array}$ & $\begin{array}{c}100 \\
\mu \mathrm{L} \\
\text { (inclu } \\
\text { ding } \\
\text { the } \\
\text { dead } \\
\text { volum } \\
\text { e) }\end{array}$ & $\begin{array}{c}<1 \\
\text { AU/mL: } \\
\text { Negative } \\
\geq 1 \\
\text { AU/mL: } \\
\text { Positive }\end{array}$ & $\begin{array}{l}100 \% \\
(\geq 15 \\
\text { days })\end{array}$ & $98.5 \%$ & 20.3 & (17) \\
\hline $\begin{array}{c}\text { Ortho } \\
\text { Clinical } \\
\text { Diagnos } \\
\text { tics }\end{array}$ & $\begin{array}{c}\text { Ortho } \\
\text { VITR } \\
\text { OS® } \\
\text { anti- } \\
\text { SARS- } \\
\text { CoV-2 } \\
\text { Total } \\
\text { Ab }\end{array}$ & CLIA & $\begin{array}{l}\text { S (S1 } \\
\text { subun } \\
\text { it) }\end{array}$ & $\begin{array}{l}20 \mu \mathrm{L} \\
\text { (this } \\
\text { volum } \\
\text { e does } \\
\text { not } \\
\text { includ } \\
\text { e the } \\
\text { dead } \\
\text { volum } \\
\text { e }\end{array}$ & $\begin{array}{l}<1.0 \mathrm{~S} / \mathrm{C}: \\
\text { Negative } \\
\geq 1.0 \mathrm{~S} / \mathrm{C} \text { : } \\
\text { Positive }\end{array}$ & NR & $100 \%$ & 17.8 & (18) \\
\hline
\end{tabular}

102 NR: Not reported

103 *CLIA, Chemiluminescence Immunoassay; ELFA, Enzyme-Linked Fluourescent Assay; S:

104 Spike Protein; N: Nucleocapsid Protein; S1: Subunit of the Spike Protein. NA: Not

105 Applicable.

106

107

$108 \quad 2.4$ cPass Genscript sVNT 
medRxiv preprint doi: https://doi.org/10.1101/2022.01.04.22268754; this version posted January 5, 2022. The copyright holder for this preprint (which was not certified by peer review) is the author/funder, who has granted medRxiv a license to display the preprint in perpetuity.

All rights reserved. No reuse allowed without permission.

A SARS-CoV-2 surrogate virus neutralization test (sVNT) (Cat. No. L00847,

110 GenScript Biotech, NJ, USA) was utilized as a reference test for detecting nAbs against

111 SARS-CoV-2. The test was conducted following the manufacturer's specifications. Briefly,

112 samples and controls (provided within the kit) were diluted 1:10 with the sample dilution

113 buffer provided with the kit. Then, $125 \square \mu \mathrm{L}$ of sample/control was mixed in a 1:1 ratio with

114 HRP-RBD solution and incubated at $37^{\circ} \mathrm{C}$ for 30 minutes. After that, $100 \square \mu l$ of each

115 sample/control was added to the hACE2 coated plate in duplicates. The plate was sealed and

116 incubated for 15 minutes at $37^{\circ} \mathrm{C}$. Wells were then washed $4 \mathrm{x}$ with $200 \square \mu \mathrm{l}$ of the wash

117 solution provided. $100 \square \mu l$ of the TMB solution was added per well and the plate was

118 incubated in the dark for 15 minutes at room temperature. Finally, $50 \mu \mathrm{L}$ of stop solution was

119 added to each well to quench the reaction, and absorbance was read at $450 \square \mathrm{nm}$. \% inhibition

120 of $\geq 30 \%$ was considered positive, and percent inhibition of $<30 \%$ was considered negative.

121 Conversion tool for cPass \% inhibition to IU/mL of the WHO International Standard (NIBSC

122 code 20/136) was calculated as established in this (10).

123

124

\subsection{Statistical method}

Correlation and linear regression analysis between FinecareTM and each commercial serological immunoassay and the sVNT were performed. Pearson correlation coefficient (r) was calculated. For absolute values of Pearson's r, $0-0.19$ is denoted as very weak, $0.2-0.39$ as weak, $0.40-0.59$ as moderate, $0.6-0.79$ as strong, and $0.8-1$ as very strong correlation (19). Concordance analysis between FinecareTM and the three automated assays was conducted, which includes the overall percent agreement (OPA), positive percent agreement (PPA), and negative percent agreement (NPA), accuracy/efficiency as well as Cohen's Kappa statistic. Cohen's Kappa measure is a robust metric that estimates the level of agreement between two diagnostic tests. A Kappa value $<0.40$ denotes poor agreement, $0.40-0.59$ denotes fair agreement, $0.60-0.74$ denotes good agreement, and $\geq 0.75$ denotes excellent agreement (20). 
medRxiv preprint doi: https://doi.org/10.1101/2022.01.04.22268754; this version posted January 5, 2022. The copyright holder for this preprint (which was not certified by peer review) is the author/funder, who has granted medRxiv a license to display the preprint in perpetuity.

All rights reserved. No reuse allowed without permission.

135 The significance level was indicated at 5\%, and a 95\% confidence interval (CI) was reported

136 for each metric. All statistical analysis was performed using GraphPad Prism software

137 (Version 8.2.1. San Diego, CA, USA).

138 3. Results

139

140 3.1. FinecareTM is a very specific and sensitive assay

141 To assess the specificity of the of the FinecareTM, we tested 100 pre-pandemic

142 plasma samples using FinecareTM as well as sVNT as a reference method. None of the tested

143 samples were positive by any of the two assay, indicating $100 \%$ specificity of the

144 FinecareTM. Regarding the sensitivity, 156 plasma samples were tested by the sVNT and the

145 FinecareTM. 155 samples were positive by sVNT and FinecareTM. However, only one

146 sample tested negative with sVNT but positive with FinecareTM indicating $99.8 \%$ sensitivity

147 of the FincareTM. Intrestingly this sample tested negative when fingerstick whole blood

148 sample were tested. The discripency between the reslts of plasma and fingerstick could be

149 due to a technical error between the two different technichains who performed the test.

150 3.2. FinecareTM fingerstick and plasma results are comparable

159 We assessed the performance of FinecareTM using fingerstick whole blood samples.

160 A total of 156 participants provided informed consent to receive a fingerstick and have

161 venous blood drawn to generate matched plasma samples. These samples were tested using

162 the FinecareTM and results were compared as shown in Figure 1. A very strong correlation

163 was observed $(r=0.9, \mathrm{P}<0.0001)$ between fingerstick and venous plasma samples. Similarly,

164 linear regression analysis showed that constructed model could strongly predict the

165 dependent variable $\left(\mathrm{R}^{2}=0.8, \mathrm{p}<0.0001\right)$. Most importantly, the interpretation concordance was

$166100 \%$, demonstrating equivalency between fingerstick and venous plasma. 
A)

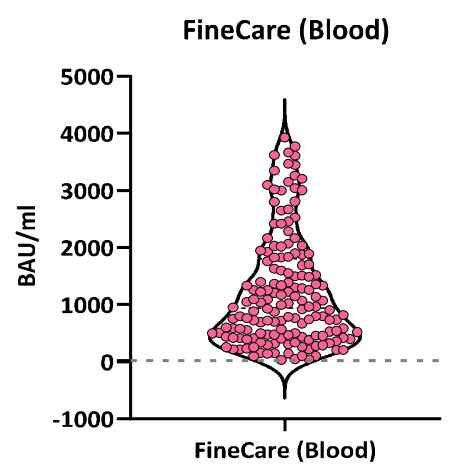

B)

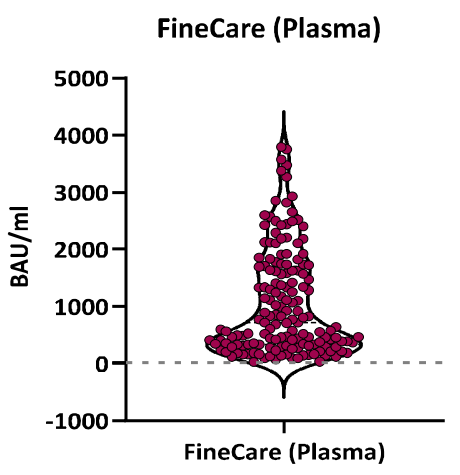

C)

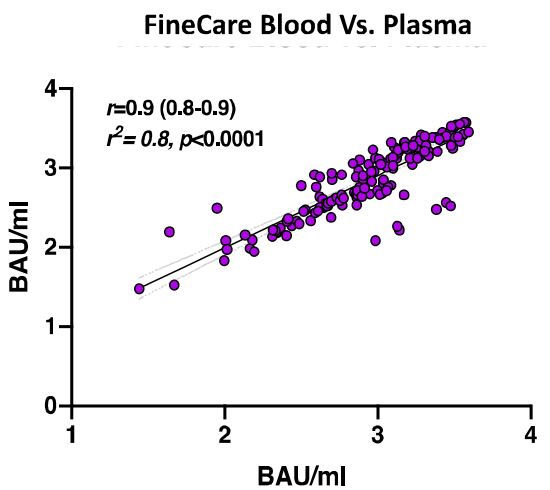

171 coefficient $(r)$, coefficient of determination $\left(\mathrm{R}^{<}\right)$, and $p$-value are shown.

\subsection{Moderate correlation between FinecareTM and sVNT}

174 We evaluated the performance of FinecareTM in comparison to sVNT. Moderate

175 significant correlation between FinecareTM and sVNT with $r$-value of 0.5 (p $\square<\square 0.001$ ) was

176 shown in Figure 2. Most importantly, the interpretation concordance was $99.4 \%$ as only one

177 sample tested negative with sVNT but positive with FinecareTM. 
A)

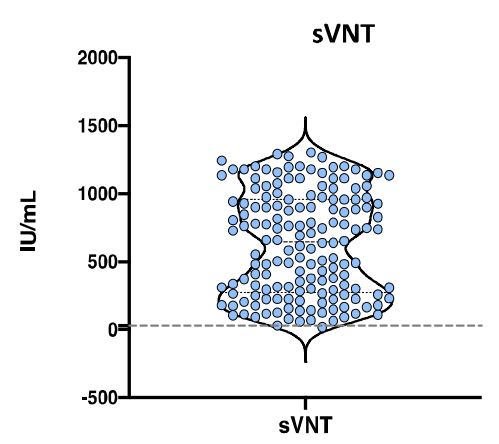

B)

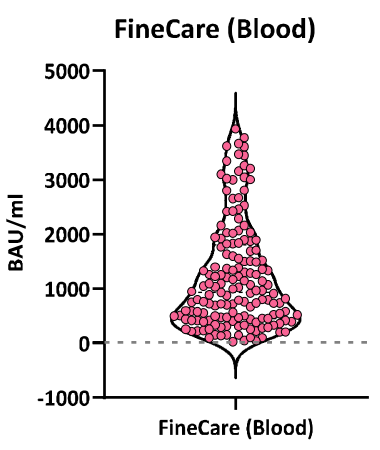

C)

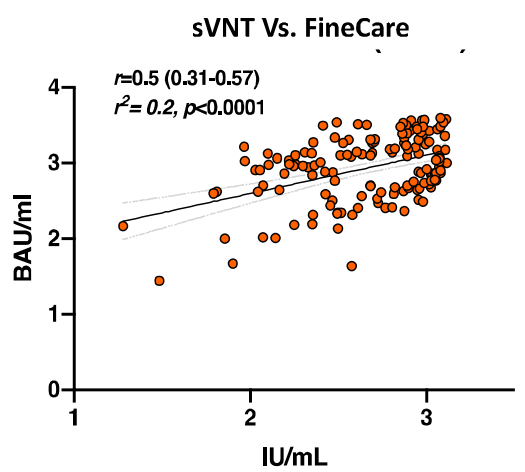

178 FinecareTM and each automated immunoassay are illustrated in Figure 3. Pearson's correlation coefficients ( $r$ ) showed a statistically significant positive correlation for FinecareTM with all three automated assays $(\mathrm{p}<0.001)$. The strongest correlation coefficient was shown with VIDAS $® 3(r=0.6$, Figure 3A), followed by VITROS $®(r=0.5$, Figure 3C), and CL-900i ${ }^{\circledR}(r=0.4$, Figure 3B). Linear regression analysis showed that all constructed models could statistically significantly predict the dependent variable [Fine care (BAU/mL)].

192 The best regression model fitting the data was shown by VIDAS $® 3\left(\mathrm{R}^{2}=0.3\right)$, followed by $\operatorname{VITROS}\left(\mathrm{R}^{2}=0.3\right)$ and CL-900i® $\left(\mathrm{R}^{2}=0.2\right)$. 
A)

FineCare vs. VIDAS

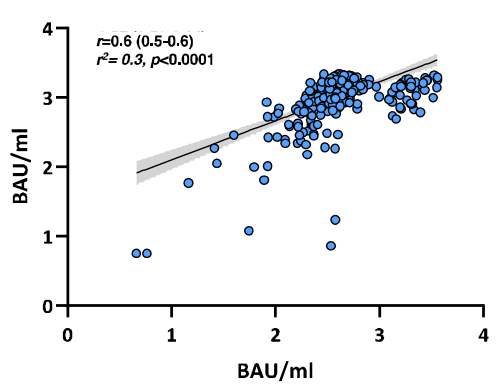

B)

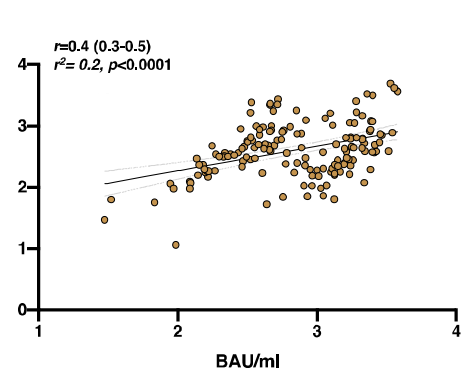

C)

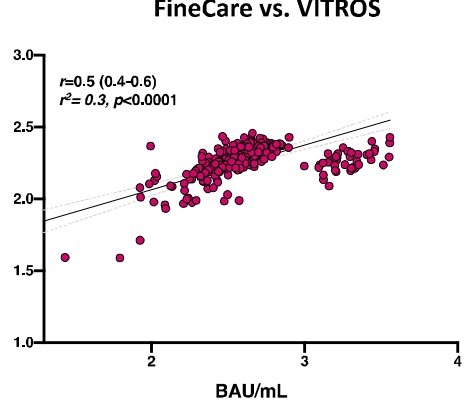

196

\subsection{Excellent agreement between FinecareTM and the three automated anti-SARS-}

\section{CoV-2 immunoassays}

The tests' agreements were studied in a pairwise fashion applying inter-rater agreement statistics; (Cohen's Kappa statistic, k) (Table 2). The OPA, PPA, NPA were 100\% between FinecareTM and the three automated immunoassays. In addition, Cohen's Kappa statistic denoted excellent agreement between FinecareTM and the three automated antiSARS-CoV-2 immunoassays $(\kappa=1.00)$. Most importantly, the interpretation concordance was $100 \%$, demonstrating equivalency between FinecareTM and the three automated antiSARS-CoV-2 immunoassays. 
medRxiv preprint doi: https://doi.org/10.1101/2022.01.04.22268754; this version posted January 5, 2022. The copyright holder for this preprint (which was not certified by peer review) is the author/funder, who has granted medRxiv a license to display the preprint in perpetuity.

All rights reserved. No reuse allowed without permission.

212 Table 2. Concordance assessment between FinecareTM and the three automated anti-SARS-

213 CoV-2 immunoassays (CL-900i®, VIDAS®3, and VITROS®).

\begin{tabular}{|c|c|c|c|c|c|c|}
\hline Test & $\begin{array}{c}\text { Compared } \\
\text { to }\end{array}$ & $\begin{array}{c}\text { Overall } \\
\text { Percent } \\
\text { Agreement } \\
\text { (OPA) }\end{array}$ & $\begin{array}{c}\text { Positive } \\
\text { Percent } \\
\text { Agreement } \\
\text { (PPA) }\end{array}$ & $\begin{array}{l}\text { Negative } \\
\text { Percent } \\
\text { Agreement } \\
\text { (NPA) }\end{array}$ & $\begin{array}{l}\text { Accuracy/ } \\
\text { Efficiency }\end{array}$ & $\begin{array}{l}\text { Cohen's } \\
\text { Kappa } \\
\text { Statistic }\end{array}$ \\
\hline & & $\%(95 \% \mathrm{CI})$ & $\%(95 \% \mathrm{CI})$ & $\%(95 \% \mathrm{CI})$ & $\%(95 \% \mathrm{CI})$ & $\mathrm{k}(95 \% \mathrm{CI})$ \\
\hline \multirow[t]{3}{*}{$\begin{array}{c}\text { Finecare } \\
\text { TM }\end{array}$} & VIDAS®3 & $\begin{array}{c}100(98.90- \\
100)\end{array}$ & $\begin{array}{c}100(98.90- \\
100)\end{array}$ & $\begin{array}{c}100(2.5- \\
100.00)\end{array}$ & $\begin{array}{c}100(98.90- \\
100.00)\end{array}$ & $\begin{array}{c}1.00(0 \\
0.40-0.86)\end{array}$ \\
\hline & CL-900i® & $\begin{array}{c}100( \\
99.25-100.00)\end{array}$ & $\begin{array}{c}100(99.25- \\
100.00)\end{array}$ & $\begin{array}{c}100(15.81- \\
100)\end{array}$ & $\begin{array}{c}100( \\
99.25- \\
100.00)\end{array}$ & $\begin{array}{c}1.00(0.52 \\
\text { to } 0.96)\end{array}$ \\
\hline & VITROS® & $\begin{array}{c}100(98.85- \\
100)\end{array}$ & $\begin{array}{c}100(98.84- \\
100)\end{array}$ & $\begin{array}{c}100(2.5- \\
100.00)\end{array}$ & $\begin{array}{c}100(98.85- \\
100.00)\end{array}$ & $\begin{array}{c}1.00(0 \\
0.46-0.95)\end{array}$ \\
\hline
\end{tabular}

216 4. Discussion

217

218 Despite this rapid progress in vaccines development, it is unlikely that COVID-19

219 will be eradicated in the near future. At best, COVID-19 infections can be brought under

220 control to the point where life can return to "pre-COVID" normality (21). A key part of this

221 approach will be the deployment of high throughput testing to determine who is immune and

222 the duration of immune response (21). The rapid LFA-POC antibody tests are simple, cheap,

223 and fast. They do not require qualified personnel for interpretation and could be done in non-

224 laboratory settings. The usefulness of rapid tests for detection of SARS-CoV-2 Abs has been

225 questioned regarding their inferiority compared to other serology assays. This is because

226 none of the few commercially available LFAs provide quantitative measurement of SARS-

227 CoV-2 (in BAU/mL) to the S-RBD. The FinecareTM2019-nCoV S-RBD Antibody Test used

228 along FinecareTM reader is the first quantitative LFA for the detection of S-RBD BAU in

229 human fingerstick whole blood, venipuncture whole blood, and serum or plasma specimens 
medRxiv preprint doi: https://doi.org/10.1101/2022.01.04.22268754; this version posted January 5, 2022. The copyright holder for this preprint (which was not certified by peer review) is the author/funder, who has granted medRxiv a license to display the preprint in perpetuity.

All rights reserved. No reuse allowed without permission.

230 (12). WHO International Standard (BAU/mL) is essential for facilitating the standardization

231 of SARS-CoV-2 serological methods and allow for comparison and harmonization of

232 datasets across laboratories. This is critical for determining the antibody levels that are

233 needed for efficacious vaccines and protection from emerging variants such as Omicron (22).

234 Recent studies have shown that two-dose COVID-19 vaccine regimen do not induce enough

235 neutralizing antibodies against the Omicron variant (22).

236 One of the major advantages of FinecareTM is using fingerstick whole blood samples 237 and obtaining quantitative results within 15 minutes. Although Abs are more stable in 238 serum/plasma samples, the whole blood samples are more convenient to use. Therefore, we 239 assessed the performance of FinecareTM using fingerstick whole blood samples compared to 240 venous plasma samples. A very strong correlation was observed $(r=0.9, \mathrm{P}<0.0001)$ between

241 fingerstick and venous plasma samples. In addition, the interpretation concordance was 100\%,

242 demonstrating equivalency between fingerstick whole blood and venous plasma samples. Our

243 results confirmed the feasibility of using fingerstick whole blood for SARS-CoV-2 IgG

244 detection and showed excellent concordance with plasma values using FinecareTM assay.

245 Collection of fingerstick whole blood samples in Microtainer tubes is quick and easy. It does

246 not require a phlebotomist, making it an attractive alternative to venepuncture for use in

247 SARS-CoV-2 drive-through testing sites. The simplicity of performing the LFA with whole

248 blood also eliminates the need for centrifugation and plasma separation steps, reducing the

249 cost and complexity of obtaining a result.

250 FinecareTM, which targets S-RBD antibodies, showed a moderate degree of 251 correlation $(r=0.5, \mathrm{p} \square<0.001)$ with the sVNT and demonstrated $100 \%$ specificity (data not 252 shown). Most importantly, the interpretation concordance between FinecareTM and sVNT 253 reached $99.4 \%$. S-RBD plays an essential role in viral entry into the cells suggesting 254 neutralizing properties and immunity against SARS-CoV-2 (5-8). Studies have shown that 
medRxiv preprint doi: https://doi.org/10.1101/2022.01.04.22268754; this version posted January 5, 2022. The copyright holder for this preprint (which was not certified by peer review) is the author/funder, who has granted medRxiv a license to display the preprint in perpetuity.

All rights reserved. No reuse allowed without permission.

255 serology assays that detect Abs against the S1 subunit or the RBD alone strongly correlate 256 with neutralization activity (23-27). According to McAndrews et al., approximately $86 \%$ of

257 individuals positive for S-RBD-binding Abs exhibited neutralizing capacity (3). Whereas

258 Abs directed against the Nucleocapsid protein (NP) are only binding Abs with no neutralizing 259 activity $(3,28)$.

260 The correlation and linear regression analysis between the readings obtained from

261 FinecareTM and each automated anti-SARS-CoV-2 immunoassay was evaluated. Each assay 262 was selected for previously determined performance $(13,14)$, ease-of-use characteristics 263 (automated serology) and availability. Pearson's correlation coefficients (r) showed a 264 statistically significant positive correlation between FinecareTM and all three automated 265 assays $(\mathrm{p}<0.001)$. The strongest correlation was shown with VIDASß3 $(r=0.6)$, followed by 266 VITROS $®(r=0.5)$, and $\mathrm{CL}-900 \mathrm{i} \AA(r=0.4)$. The best correlation with VIDAS®3 was 267 expected as both assays are based on fluorescence immunoassay technology and solely target 268 Abs against S-RBD. Cohen's Kappa statistic denoted excellent agreement between 269 FinecareTM and the three automated anti-SARS-CoV-2 immunoassays. Interestingly, the 270 interpretation concordance was $100 \%$, demonstrating equivalency between FinecareTM and 271 the three automated immunoassays. The excellent concordance between the POC 272 FinecareTM and the automated serological assay makes it an attractive alternative for 273 serological assays that do not require laboratory settings. The ability to rapidly, accurately, 274 and affordably determine seroprevalence in a population will be an important tool in the 275 growing arsenal of SARS-CoV-2 diagnostic testing and assessment of antibody response 276 post-vaccination, particularly in resource-limited areas.

277 In conclusion, SARS-CoV-2 continues to spread and threatens to disrupt human activity for 278 years to come. Fortunately, we already have vaccines that effectively reduce disease and are 279 now being rolled out in many countries but countering that many countries have low vaccine 
medRxiv preprint doi: https://doi.org/10.1101/2022.01.04.22268754; this version posted January 5, 2022. The copyright holder for this preprint (which was not certified by peer review) is the author/funder, who has granted medRxiv a license to display the preprint in perpetuity.

All rights reserved. No reuse allowed without permission.

280 coverage and ongoing high rates of infection, raising the potential for immune-mediated

281 selection escape variants. FinecareTM should contribute to more widespread access to

282 immunity testing for many populations, including those in resource-poor areas with limited

283 access to laboratories and equipment for more conventional virus neutralization tests or

284 ELISA-based inhibition assays.

285

\section{5. Author contributions}

287 Conceptualization, GKN and LJA.; methodology, FMS, DWA, FMH, AES, BYH, ST, SAB, 288 AA, RA, SA, JP, and AS; software, FMS, DWA, FMH, AES, BYH, SAB, AA, RA, SA, JP, 289 and AS.; validation, FMS, DWA, FMH, AES, BYH, SAB, AA, RA, SA, JP, and AS.; formal

290 analysis, GKN, FMS, HTZ, and NY investigation, GKN and LJA.; resources, GKN, LJA,

291 and AA.; data curation, GKN, FMS, HTZ, and NY.; writing-original draft preparation, NY,

292 DWA, and GKN; writing — review and editing, HID, HA, AFM and GKN.; visualization

293 GKN, FMS, HTZ, and NY.; supervision, HA, AA, HMY, and GKN.; project administration,

294 GKN and LJA.; funding, GKN, LJA, and AA. All authors have read and agreed to the

295 published version of the manuscript.

296 6. Conflict of interest

297 GKN would like to declare that all test kits used in this study were provided as in-kind 298 support for his lab to test seroprevalence of anti-SARS-CoV-2 and antibody response among vaccinated and infected individuals in Qatar.

\section{Funding:}

This work was made possible by grant number UREP28-1733- 057 from the Qatar National

302 Research Fund (a member of Qatar Foundation). The statements made herein are solely the

303 responsibility of the authors.

\section{Ethical approval:}


medRxiv preprint doi: https://doi.org/10.1101/2022.01.04.22268754; this version posted January 5, 2022. The copyright holder for this preprint (which was not certified by peer review) is the author/funder, who has granted medRxiv a license to display the preprint in perpetuity.

All rights reserved. No reuse allowed without permission.

305 The study was reviewed and approved by the Institutional Review Board at Qatar

306 University (QU-IRB 1537-FBA/21). All analyses were conducted according to the ethical

307 standards of the Declaration of Helsinkiof the World Medical Association (WMA).

308

309 
medRxiv preprint doi: https://doi.org/10.1101/2022.01.04.22268754; this version posted January 5, 2022. The copyright holder for this preprint (which was not certified by peer review) is the author/funder, who has granted medRxiv a license to display the preprint in perpetuity.

All rights reserved. No reuse allowed without permission.

\section{References}

1. Bond K, Nicholson S, Lim SM, Karapanagiotidis T, Williams E, Johnson D, et al. Evaluation of Serological Tests for SARS-CoV-2: Implications for Serology Testing in a Low-Prevalence Setting. J Infect Dis. 2020;222(8):1280-8.

2. Younes N, Al-Sadeq DW, Al-Jighefee H, Younes S, Al-Jamal O, Daas HI, et al. Challenges in Laboratory Diagnosis of the Novel Coronavirus SARS-CoV-2. Viruses. 2020;12(6).

3. McAndrews KM, Dowlatshahi DP, Dai J, Becker LM, Hensel J, Snowden LM, et al. Heterogeneous antibodies against SARS-CoV-2 spike receptor binding domain and nucleocapsid with implications for COVID-19 immunity. JCI Insight. 2020;5(18). 4. Dispinseri S, Secchi M, Pirillo MF, Tolazzi M, Borghi M, Brigatti C, et al. Neutralizing antibody responses to SARS-CoV-2 in symptomatic COVID-19 is persistent and critical for survival. Nature Communications. 2021;12(1):2670.

5. Premkumar L, Segovia-Chumbez B, Jadi R, Martinez DR, Raut R, Markmann A, et al. The receptor binding domain of the viral spike protein is an immunodominant and highly specific target of antibodies in SARS-CoV-2 patients. Sci Immunol. 2020;5(48).

6. Zhao J, Yuan Q, Wang H, Liu W, Liao X, Su Y, et al. Antibody Responses to SARSCoV-2 in Patients With Novel Coronavirus Disease 2019. Clin Infect Dis. 2020;71(16):202734.

7. Traugott M, Aberle SW, Aberle JH, Griebler H, Karolyi M, Pawelka E, et al. Performance of Severe Acute Respiratory Syndrome Coronavirus 2 Antibody Assays in Different Stages of Infection: Comparison of Commercial Enzyme-Linked Immunosorbent Assays and Rapid Tests. J Infect Dis. 2020;222(3):362-6.

8. Okba NMA, Müller MA, Li W, Wang C, GeurtsvanKessel CH, Corman VM, et al. Severe Acute Respiratory Syndrome Coronavirus 2-Specific Antibody Responses in Coronavirus Disease Patients. Emerg Infect Dis. 2020;26(7):1478-88.

9. Khoury DS, Wheatley AK, Ramuta MD, Reynaldi A, Cromer D, Subbarao K, et al. Measuring immunity to SARS-CoV-2 infection: comparing assays and animal models. Nature Reviews Immunology. 2020;20(12):727-38.

10. Zhu F, Althaus T, Tan CW, Costantini A, Chia WN, Van Vinh Chau N, et al. WHO international standard for SARS-CoV-2 antibodies to determine markers of protection. The Lancet Microbe.

11. Knezevic I, Mattiuzzo G, Page M, Minor P, Griffiths E, Nuebling M, et al. WHO International Standard for evaluation of the antibody response to COVID-19 vaccines: call for urgent action by the scientific community. The Lancet Microbe.

12. Wondfo. Finecare 2019-nCoV RBD Antibody Test 2021 [Available from: https://www.finecare.it/wp-content/uploads/2021/04/W290 RBD Antibody Binder.pdf. 13. Younes S, Al-Jighefee H, Shurrab F, Al-Sadeq DW, Younes N, Dargham SR, et al. Diagnostic Efficiency of Three Fully Automated Serology Assays and Their Correlation with a Novel Surrogate Virus Neutralization Test in Symptomatic and Asymptomatic SARSCOV-2 Individuals. Microorganisms. 2021;9(2).

14. Ismail A, Shurrab FM, Al-Jighefee HT, Al-Sadeq DW, Qotba H, Al-Shaar IA, et al. Can commercial automated immunoassays be utilized to predict neutralizing antibodies after SARS-CoV-2 infection? A comparative study between three different assays. Front Biosci (Landmark Ed). 2021;26(7):198-206.

15. Nuccetelli M, Pieri M, Grelli S, Ciotti M, Miano R, Andreoni M, et al. SARS-CoV-2 infection serology: a useful tool to overcome lockdown? Cell Death Discov. 2020;6:38-.

16. IgG(CLIA) ICM-C-MS-C-. 2020 [Available from: https://www.mindray.com/en/product/CL-900i.html. 
medRxiv preprint doi: https://doi.org/10.1101/2022.01.04.22268754; this version posted January 5, 2022. The copyright holder for this preprint (which was not certified by peer review) is the author/funder, who has granted medRxiv a license to display the preprint in perpetuity.

All rights reserved. No reuse allowed without permission.

359 17. BIOMÉRIEUX. VIDAS® SARS-COV-2 2020 [Available from:

360 https://www.biomerieux-diagnostics.com/vidas-sars-cov-2

361 18. VIPA-S-C-TRP-If U. VITROS Immunodiagnostic Products Anti-SARS-CoV-2 Total

362 Reagent Pack-Instructions for Use. 2021 [Available from:

363 https://www.fda.gov/media/136967/download.

364 19. Miot HA. Correlation analysis in clinical and experimental studies. J Vasc Bras.

365 2018;17(4):275-9.

366 20. Kirch W. Kappa coefficient. In Encyclopedia of Public Health. Springer: Dordrecht,

367 The Netherlands. 2008:821-2.

368 21. Fulford TS, Van H, Gherardin NA, Zheng S, Ciula M, Drummer HE, et al. A point-

369 of-care lateral flow assay for neutralising antibodies against SARS-CoV-2. EBioMedicine.

$370 \quad 2021 ; 74: 103729$.

371 22. Lu L, Mok BW, Chen LL, Chan JM, Tsang OT, Lam BH, et al. Neutralization of

372 SARS-CoV-2 Omicron variant by sera from BNT162b2 or Coronavac vaccine recipients.

373 Clin Infect Dis. 2021.

374 23. Tan CW, Chia WN, Qin X, Liu P, Chen MIC, Tiu C, et al. A SARS-CoV-2 surrogate

375 virus neutralization test based on antibody-mediated blockage of ACE2-spike protein-

376 protein interaction. Nature Biotechnology. 2020;38(9):1073-8.

377 24. Valcourt EJ, Manguiat K, Robinson A, Chen JC, Dimitrova K, Philipson C, et al.

378 Evaluation of a commercially-available surrogate virus neutralization test for severe acute

379 respiratory syndrome coronavirus-2 (SARS-CoV-2). Diagn Microbiol Infect Dis.

$380 \quad 2021 ; 99(4): 115294$.

381 25. Tang MS, Case JB, Franks CE, Chen RE, Anderson NW, Henderson JP, et al.

382 Association between SARS-CoV-2 Neutralizing Antibodies and Commercial Serological

383 Assays. Clin Chem. 2020;66(12):1538-47.

384 26. Hörber S, Soldo J, Relker L, Jürgens S, Guther J, Peter S, et al. Evaluation of three

385 fully-automated SARS-CoV-2 antibody assays. Clin Chem Lab Med. 2020;58(12):2113-20.

386 27. Seydoux E, Homad LJ, MacCamy AJ, Parks KR, Hurlburt NK, Jennewein MF, et al.

387 Characterization of neutralizing antibodies from a SARS-CoV-2 infected individual. bioRxiv :

388 the preprint server for biology. 2020:2020.05.12.091298.

389 28. Rump A, Risti R, Kristal M-L, Reut J, Syritski V, Lookene A, et al. Dual ELISA

390 using SARS-CoV-2 nucleocapsid protein produced in E. coli and CHO cells reveals epitope

391 masking by N-glycosylation. Biochem Biophys Res Commun. 2021;534:457-60.

392 
medRxiv preprint doi: https://doi.org/10.1101/2022.01.04.22268754; this version posted January 5, 2022. The copyright holder for this preprint (which was not certified by peer review) is the author/funder, who has granted medRxiv a license to display the preprint in perpetuity.
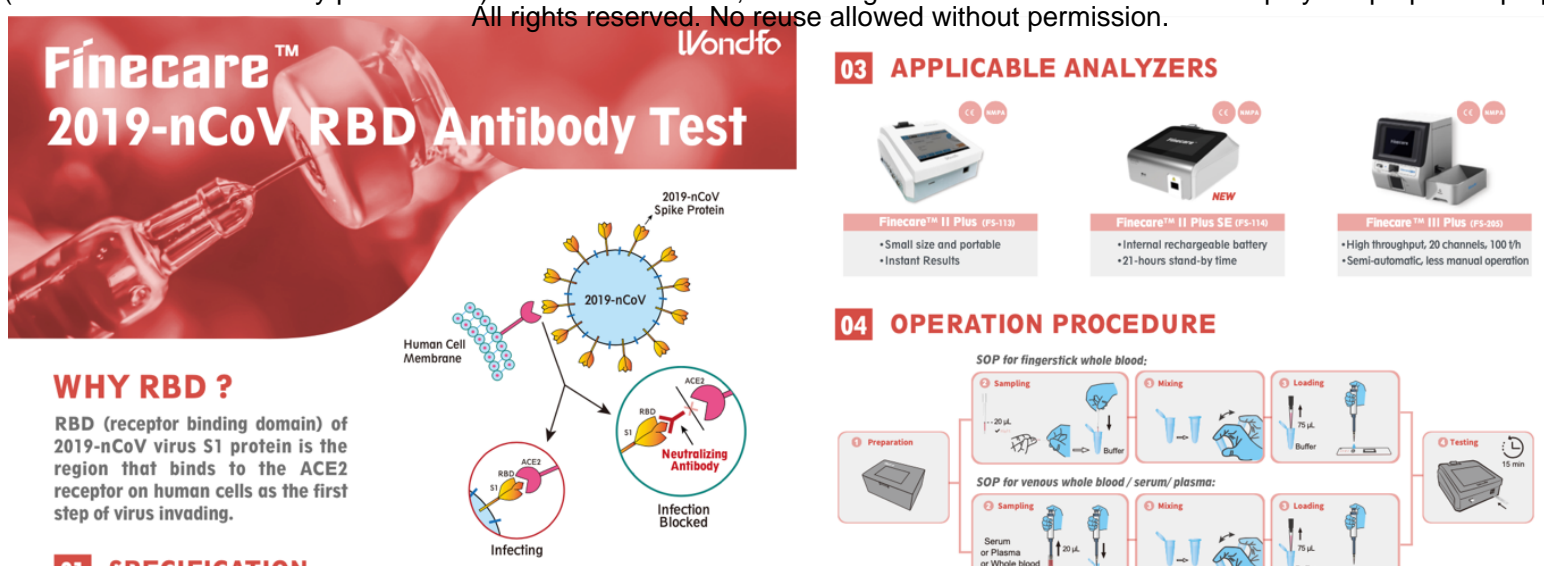

04 OPERATION PROCEDURE
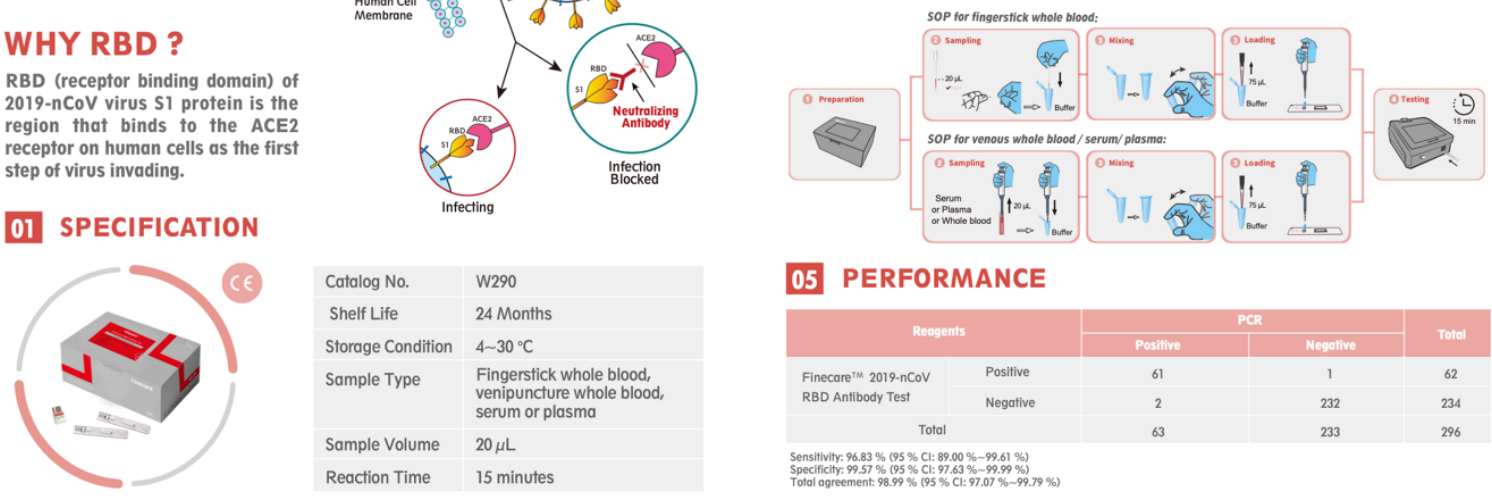

05 PERFORMANCE

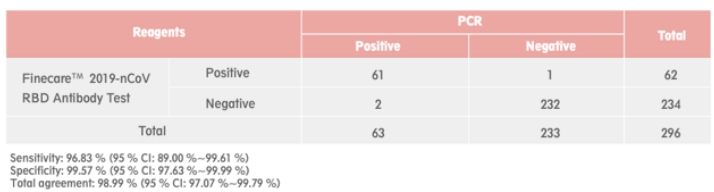

02 APPLICATION

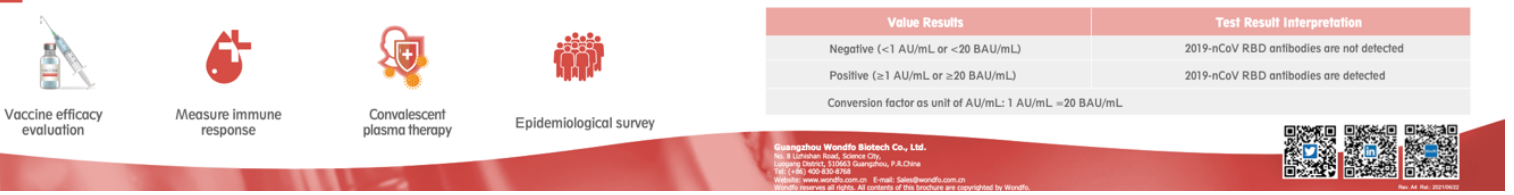

Figure S1 overview of FinecareTM2019-nCoV S-RBD lateral flow assay principle. 